\title{
DESIGN AND DEVELOP AUTOMATION SYSTEM FOR SAVING ELECTRICAL ENERGY IN THE STTAL OFFICE ROOM
}

\author{
Sutrisno, Wawan Kusdiana, Amri Rahmatullah, Bagiyo Herwono \\ Indonesian Naval Technology College \\ Bumimoro-Morokrembangan, Surabaya 60187, Indonesia
}

\begin{abstract}
The use of electricity in offices has been considered too wasteful. This is caused by human negligence in controlling their use. For this reason, this research was carried out as an effort to find the right method to reduce the high electricity consumption in offices. This research was conducted in the STTAL classroom, Bumimoro, Surabaya. From the results of the calculation, the total heat load in the classroom is 32,048.3 BTU or \pm 4 PK. Total installed AC capacity is only 2 PK. This automation tool is a system that works automatically to regulate the use of electrical equipment based on parameters that have been determined in a program such as the presence or absence of humans, the level of light intensity and room temperature. Data collection is carried out for 6 days in the classroom, 3 days without tools and 3 days using the automation tool. Furthermore, the data is compared to the graph and the savings are calculated. The result, on day 1 is $56.11 \%$, days 2 and 3 are $10.26 \%$ and the average savings for the 6-day trial is $33.43 \%$. All data is recorded automatically on a micro sdcard and information about the amount of electricity consumption and the ON / OFF feature of electrical equipment can also be accessed via a smartphone with a wifi network so that users will find it easier to monitor the use of electrical equipment in the classroom.
\end{abstract}

Keywords: electricity waste, heat load, automation system, electricity monitoring, electricity savings.

\section{INTRODUCTION}

National electricity consumption increases every year in line with the increase in national economic growth. To meet the increasing electricity demand, the Government has sought to accelerate electricity infrastructure development by building a 35,000 MW power plant and a 45,000 Km transmission network.

High electricity consumption is found in buildings or offices. Because buildings or offices have many rooms and electrical equipment that are rather difficult to control in their use. Especially if the electrical equipment has not met electricity saving standards, of course, will be costly

high electricity every month.

One agency that consumes enough electricity is the university or campus, especially electricity consumption for lighting and air conditioning. After the room is used, lighting and air conditioning often forget not put out. Not to mention if the air conditioner does not match the ideal cooling load, it will definitely lead to high electricity consumption every day.

Many efforts have been made to reduce electricity consumption, especially in the environment of Government agencies including the TNI and especially the Navy. But there is no effective way to reduce electricity consumption to be more efficient in its use.

For this reason, it is necessary to carry out research as an effort to save electricity consumption in STTAL offices with research objects, namely electrical equipment in STTAL classrooms with the most dominant electrical load is the electric load of cooling machines, lights and projectors. This study will analyze and design an automation system that can control the use of electrical equipment and electric power loads every month. With the hope that this system can be used to save on the use of electrical energy and facilitate the control function of personnel when guarding.

The several problems studied include:

a. Is the installed cooling engine capacity compatible with the heat load in the room?

b. How does this automation system work so that it can save electricity consumption?

c. What is the effectiveness of the automation system for saving electricity consumption?

The purpose of the design of this automation system is to analyze the suitability of the cooling engine installed with room heat, designing a prototype by working an automation system that can save electricity consumption, and find the effectiveness of the system to save electricity.

The benefits obtained are as reference material, information and input to the reader about the right and optimal method to save electricity consumption and control of electrical equipment more easily by analyzing the exact heat load calculation of the room.

\section{MATERIALS AND METHODS}

\subsection{Method}

The implementation of the electrical automation system research is arranged in several systematic and planned steps. In this study the authors chose quantitative research methods. Because this method is more systematic, planned, 
and structured. Sources of data from this study are primary data in the form of data on the use of electrical loads from all electrical equipment in the STTAL classroom. There is also secondary data which is the manufacturer's specification data for each electrical equipment. Electrical equipment in question includes lights, PCs, AC (Air Conditioner) and projectors. For the subjects of this study include human activity, environmental temperature, and light intensity. Besides that the research subject is this variable or factor that influences the research results significantly and the research object uses STTAL classrooms as a sample of the STTAL office space that has been installed by this electrical automation system.

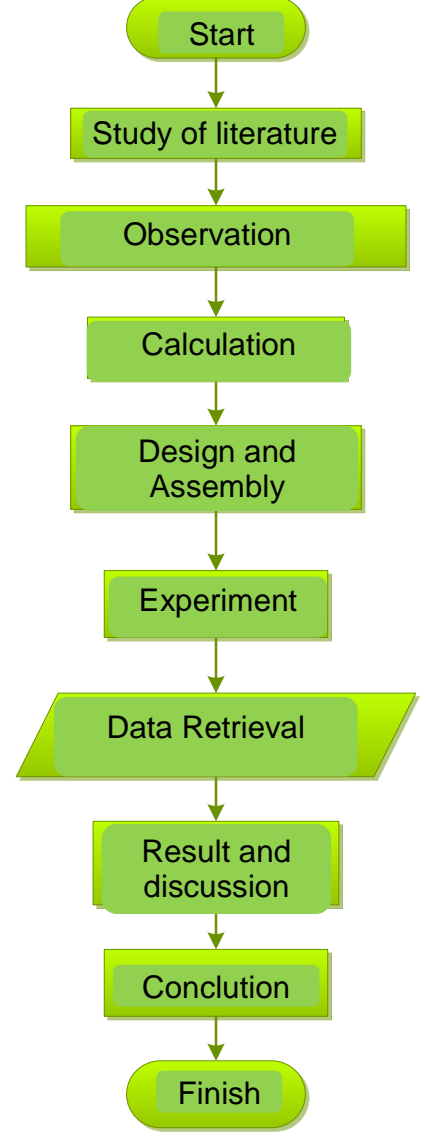

Figure1. Flowchart Diagram

\subsection{Materials}

The design of this electrical automation system uses several tools and materials as the main components so that the tool can operate in accordance with the initial concept of design. These components include:

\subsubsection{Activity Sensors (PIR)}

PIR (Passive Infrared Receiver) is a sensor that only responds to energy from passive infrared rays that are owned by every object detected by it. The IR Filter is able to filter the wavelengths of passive infrared between 8-14 micrometers with a range of \pm 10 meters.

\subsubsection{Light Sensors (LDR)}

Light sensor LDR (Light Dependent Resistor) is one type of resistor that can change resistance when experiencing changes in light reception. This means that when the light intensity regarding LDR is low, the LDR will have high resistance. Whereas in bright conditions, the resistance of the LDR will be low.

2.2.3 Temperature and Humidity Sensors (DHT22)

This temperature and humidity sensor is DHT22 which has a function to measure the amount of temperature and humidity in the surrounding air which is then converted into electrical quantities in the form of voltage. DHT22 has good quality in terms of response and fast reading of data. This sensor uses a $5 \mathrm{~V}$ voltage, temperature measurement between -40 dd. $80^{\circ} \mathrm{C}$ (accuracy $\pm 0.5 \circ \mathrm{C}$ ) and humidity $0-100 \%$ (accuracy of $2-5 \%$ ).

\subsubsection{Module Time (Real Time Clock)}

This component is needed to provide input time data both seconds, minutes, hours, days, months and years. This component is DS3231 RTC. This module is equipped with a CR2032 3V battery as a back up power when the main power supply is off. So that the RTC DS3231 module is able to update time and can record time continuously.

\subsubsection{Voltage Sensors}

The sensor used is the ZMPT101B sensor. This sensor component module consists of a step down transformer that is likened to an op-amp circuit as a comparison and will then produce an analog signal value. This analog signal will be read by Arduino as input data for the voltage in the circuit.

\subsubsection{Flow Sensors}

The sensor used is WCS1700 70A. The way it works is that the flowing current produces a magnetic field that is captured by an integrated IC field and is converted to proportional voltage. When the current flows, this IC will give a DC voltage output. The voltage value will increase directly proportional to the current value. This sensor is safe to use until the current load limit is $70 \mathrm{~A}$. The load used in this study is only up to $\pm 35 \mathrm{~A}$.

\subsubsection{Arduino Pro Mega 2560}

This type of microcontroller is a development of the type of Arduino Mega 2560 microcontroller. The specifications are the same but the size is much smaller. All supporting components in operation are packaged in a compact and small system. By function and specification, Arduino Pro Mega 2560 is exactly the same as Arduino Mega 2560.

\subsubsection{Arduino Uno}

Arduino uno is a microcontroller board based on ATmega328. Arduino uno has 14 digital input / output pins (6 of which can be used as PWM output), 6 analog inputs, a $16 \mathrm{MHz}$ Crystal oscillator, a USB connection, a power jack, an ICSP header, and a reset button. Arduino UNO loads everything needed to support a microcontroller easily. Besides that it is also easy to connect it to a 
computer with a USB cable or it can also be connected to an AC adapter to DC.

\subsubsection{Infra Red Led Module KY-05}

This module is a communication media that utilizes infrared. The emitted infrared will be received by the receiving module which is converted into a command. This module works in pairs between the transmitter and receiver. This module consists of a $5 \mathrm{~mm} \mathrm{IR} \mathrm{led} \mathrm{and} \mathrm{is} \mathrm{compatible}$ with Arduino.

\subsubsection{HC-12 Wireless Module $433 \mathrm{MHz}$}

Remote communication between Arduino can be done by connecting Arduino to a module that is capable of sending and receiving data at a considerable distance. This communication module is the $\mathrm{HC}-12$ wireless module $433 \mathrm{MHz}$. This module is capable of communicating up to a distance of 1.8 $\mathrm{Km}$. This module also works on frequencies of $433.4 \mathrm{MHz}$ to $473 \mathrm{MHz}$ and there are 100 channels that can be used and can send and receive data. This module works at a voltage of $3.2 \mathrm{~V}$ to $5.5 \mathrm{~V} \mathrm{DC}$.

\subsubsection{LCD}

LCD (Liquid Cristal Display) is used as a component that functions as a display or monitoring of the performance of a system that is operating. Display of data provided can be in the form of characters, letters, numbers or graphics.

\subsubsection{Micro Sdcard Module}

Micro sdcard is a data storage medium that is practical and easy to carry. In addition the data storage memory is also very large and is sufficient to store data for a long time. To use this micro sdcard, a micro sdcard adapter module is needed. Data reading and writing data using the SPI (Serial Parallel Interface) interface system.

\subsubsection{NodeMCU ESP8266}

NodeMCU ESP8266 is a derivative module developed from ESP8266 ESP-12 type loT (Internet of Things) platform module. Functionally this module is almost similar to the Arduino module platform, but the difference is specifically for "Connected to the Internet". In this module the user can simply connect the module to the voltage source and the system will be connected to wifi.

\subsubsection{Automatic Relay (SSR)}

The automatic switch used is Solid State Relay (SSR). The SSR is built with an insulator to separate the input parts and switch parts. Solid State Relay is able to turn on and off with a faster time with no trigger spark so there is no corrosion problem of contact.

\section{RESULTS AND DISCUSSION}

\subsection{Calculation of Cooling Load}

The class room data which is the object of research are:
a. Length
$: 8 \mathrm{~m}$
b. Width
$: 7.5 \mathrm{~m}$
c. Height : $3.45 \mathrm{~m}$
d. Wall : Brick and cement plaster
e. Ceramic floor

f. Ceiling: Asbestos

g. Door : Triplex, $\mathrm{L}=1.67 \mathrm{~m}, \mathrm{~T}=2.07 \mathrm{~m}$

h. Window: 8 pieces, @ $100 \mathrm{~cm} \times 80 \mathrm{~cm}$, ordinary glass

i. Lights : 16 pieces @ 40W

j. Occupants : 25 people

k. Laptop : 17 units, @ 30W

I. Projector : 1 unit, $132 \mathrm{~W}$

m. Desktop PC : 1 unit, 100W

n. Equipment : Table 17 units, Chair 17 units

Table 1. Room Dimensions

\begin{tabular}{|c|c|c|c|c|c|}
\hline obyek & $\begin{array}{c}\text { lenght } \\
(\mathrm{m})\end{array}$ & $\begin{array}{c}\text { width } \\
(\mathrm{m})\end{array}$ & $\begin{array}{c}\text { height } \\
(\mathrm{m})\end{array}$ & $\begin{array}{c}\text { area } \\
(\mathrm{m} 2)\end{array}$ & $\begin{array}{c}\text { volume } \\
(\mathrm{m} 3)\end{array}$ \\
\hline Classroom & 8 & 7.5 & 3.75 & 60 & 207 \\
\hline
\end{tabular}

Table 2. Wall Area

\begin{tabular}{|c|c|c|c|c|c|c|}
\hline \multirow{2}{*}{ No } & \multirow{2}{*}{ obyek } & \multicolumn{2}{|c|}{ |lenght|height } & \multirow{2}{*}{ Total } & area & \multirow{2}{*}{ Mark } \\
\hline & & (m) & (m) & & (m2) & \\
\hline \multirow{2}{*}{1} & South wall & 8 & 3,45 & 1 & 27,6 & Reduction due to \\
\hline & Window & 0,8 & 1 & 8 & 6,4 & the window \\
\hline & \multicolumn{4}{|c|}{ Area of South wall } & 21,2 & \\
\hline 2 & West wall & 7,5 & 3,45 & 1 & 25,88 & \\
\hline \multirow{2}{*}{3} & North wall & 8 & 3,45 & 1 & 27,6 & Reduction due to \\
\hline & Door & 1,67 & 2,07 & 1 & 3,5 & the door \\
\hline & \multicolumn{4}{|c|}{ Area of North wall } & 24,1 & \\
\hline 4 & East wall & 7,5 & 3,45 & 1 & 25,88 & \\
\hline
\end{tabular}

Table 3. Design Temperature

\begin{tabular}{|c|c|c|c|c|}
\hline & $\begin{array}{c}\text { Dry ball } \\
\text { Temperatur }\end{array}$ & $\begin{array}{c}\text { Daly Temperatur } \\
\text { Change }\end{array}$ & $\begin{array}{c}\text { Reative } \\
\text { humudity }\end{array}$ & $\begin{array}{c}\text { Compration of arerage humidity } \\
\text { throughout yhe day }\end{array}$ \\
\hline Indoor & $250 \mathrm{C}$ & & $50 \%$ & 0,0105 \\
\hline Outdoor & $340 \mathrm{C}$ & 9OC & & 0,02 \\
\hline
\end{tabular}

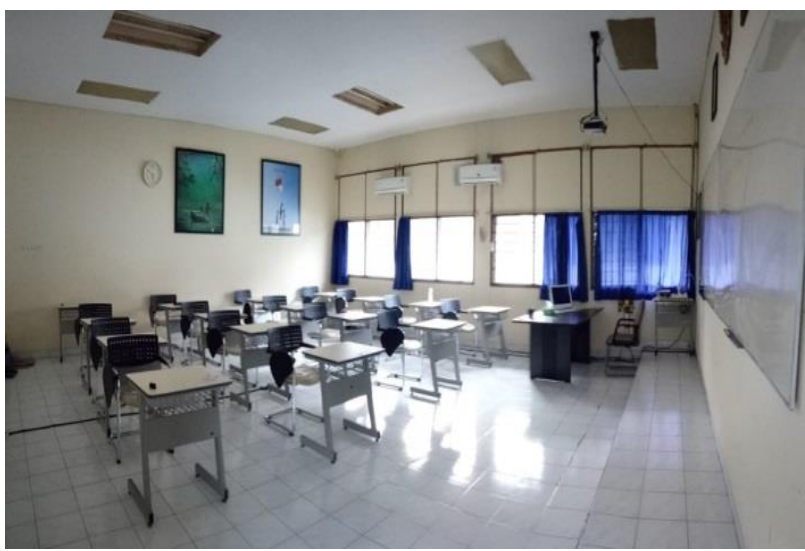

Figure 2. Classroom Conditions 


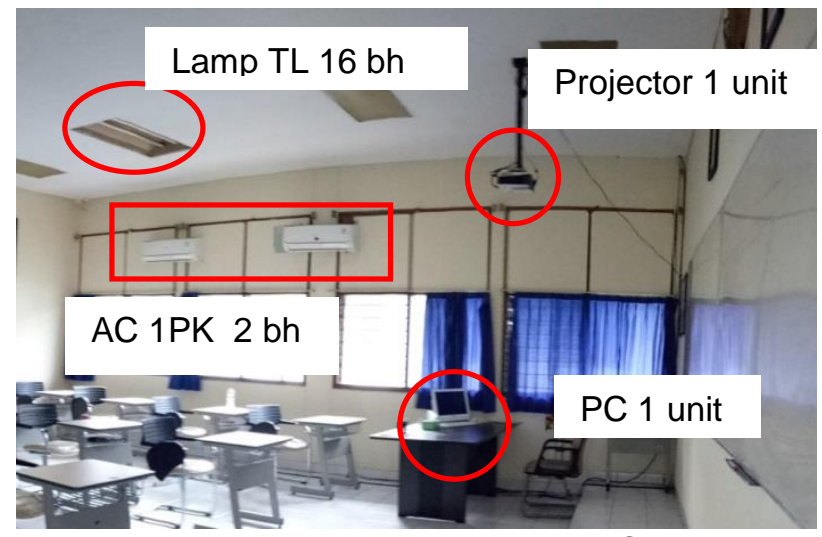

Figure 3. Electrical Equipment in the Classroom

The outside air temperature for a moment at $11.00,12.00,13.00,14.00$, and 15.00 is:

$t_{0}=34-\frac{9}{2}+\frac{9}{2} \cos 15(\tau-2)=29,5+4 \cos 15(\tau-$ 2)

Where is the time for successive solar irradiation,

$\tau=-1, \tau=0, \tau=1, \tau=2$ dan $\tau=3$, so, The hottest temperature occurs at 2:00 p.m., then the amount of the hottest solar radiation is:

$$
J n=1164 \times P^{\operatorname{cosec} h}=1164 \times(0,6)^{1 / \sin 47,6}=582,8
$$

Table 4. Outside Air Temperature

\begin{tabular}{|c|c|c|c|c|c|}
\hline Time & 11.00 & 12.00 & 13.00 & 14.00 & 15.00 \\
\hline $\begin{array}{c}\text { Outside Air } \\
\text { Temperature }\end{array}$ & 32,7 & 33,4 & 33,8 & 34 & 33,8 \\
\hline
\end{tabular}

\subsubsection{Sensible Heat of Perimeter Area (Edge)}

a. Additional heat by transmitting solar radiation through a window 93,2 $\mathrm{Kcal} / \mathrm{jam}$

b. Heat transmission load through the window $316,8 \mathrm{Kcal} / \mathrm{jam}$

c. Sensible heat load infiltration $1.841,6 \mathrm{Kcal} /$ jam.

d. Sensible heat load through walls \& roof

$Q_{\text {Dinding }}=Q_{\text {D.Selatan }}+Q_{\text {D.Utara }}$

$Q_{\text {Dinding }}=(397,7+406,9) \mathrm{Kcal} / \mathrm{jam}$

$$
=804,6 \mathrm{Kcal} / \mathrm{jam}
$$

Sensible heat load via roof $996.5 \mathrm{Kcal} /$ hour. So the total sensible heat load through walls and roof is:

$Q=(804,6+996,5) \mathrm{Kcal} / \mathrm{jam}=1.801,1 \mathrm{Kcal} / \mathrm{jam}$

e. The stored heat load from a room with air (cooling) refreshing is intermittent $810,5 \mathrm{Kcal} / \mathrm{jam}$. area

Total sensible heat load perimeter (edge)

$$
\begin{gathered}
Q=(93,2+316,8+1.841,6+1.801 \\
+810,5) \mathrm{Kcal} / \mathrm{jam} \\
=4.863,2 \mathrm{Kcal} / \mathrm{jam}
\end{gathered}
$$

\subsubsection{Latent Load Area of Perimeter (Edge)}

Latent heat load by infiltration 21,95 Kcal/jam
3.1.3 Sensible Heat Area Interior Loads

a. The transmission coefficient of the door partition $71,7 \mathrm{Kcal} / \mathrm{jam}$

b. Transmission coefficient from wall partitions

$$
Q_{\text {transmisi dinding }}=\text { D.timur }+ \text { D. barat }
$$

$$
=0 \mathrm{Kcal} / \mathrm{jam}
$$

c. Sensible heat load due to the presence of interior heat sources.

The total sensible heat load due to the presence of interior heat sources is:

$$
\begin{gathered}
Q=(1.188,5+640+0,086+0,4386 \\
\quad+0,113) \mathrm{Kcal} / \mathrm{jam} \\
=1.829,2 \mathrm{Kcal} / \mathrm{jam}
\end{gathered}
$$

Total interior sensible heat load

$Q=(71,7+1.829,2) \mathrm{Kcal} / \mathrm{jam}$

$$
=1.900,9 \frac{\mathrm{Kcal}}{\mathrm{jam}}
$$

\subsubsection{Latent Load Interior Area Interior} Latent addition of heat by interior evaporation sources 560,6 Kcal/jam.

\subsubsection{Total Sensible Heat Load}

a. Total room sensible heat load $6.764,1 \mathrm{Kcal} /$ jam.

b. Increased load by leaking airways $676,41 \mathrm{Kcal} / \mathrm{jam}$.

Total sensible heat load

$Q=$ Total room sensible heat load + Increased load by leakage.

$Q=6.764,1+676,41=7.440,51 \mathrm{Kcal} / \mathrm{jam}$

Total sensible heat load

$Q=$ Total room sensible heat load + Increased load by leakage

$Q=6.764,1+676,41=7.440,51 \mathrm{Kcal} / \mathrm{jam}$

3.1.6 Total Latent Heat Load

Total latent heat load

$Q=$ Total room latent heat load + Increased load by leakage.

$Q=582,55+58,25=640,8 \mathrm{Kcal} / \mathrm{jam}$

3.1.7 Total Cooling Load

$Q_{\text {Total }}=$ Total sensible heat load + Total latent heat load

$$
\begin{aligned}
Q_{\text {Total }} & =7.440,5+640,8 \\
& =8.081,3 \frac{\mathrm{Kcal}}{\mathrm{jam}} \times \frac{1 \mathrm{BTU} / \mathrm{jam}}{0,25216 \mathrm{Kcal} / \mathrm{jam}} \\
& =32.048,3 \mathrm{BTU} / \mathrm{jam}
\end{aligned}
$$




\subsection{Designing Prototype}

\subsubsection{Hardware Design}

a. Block Diagram

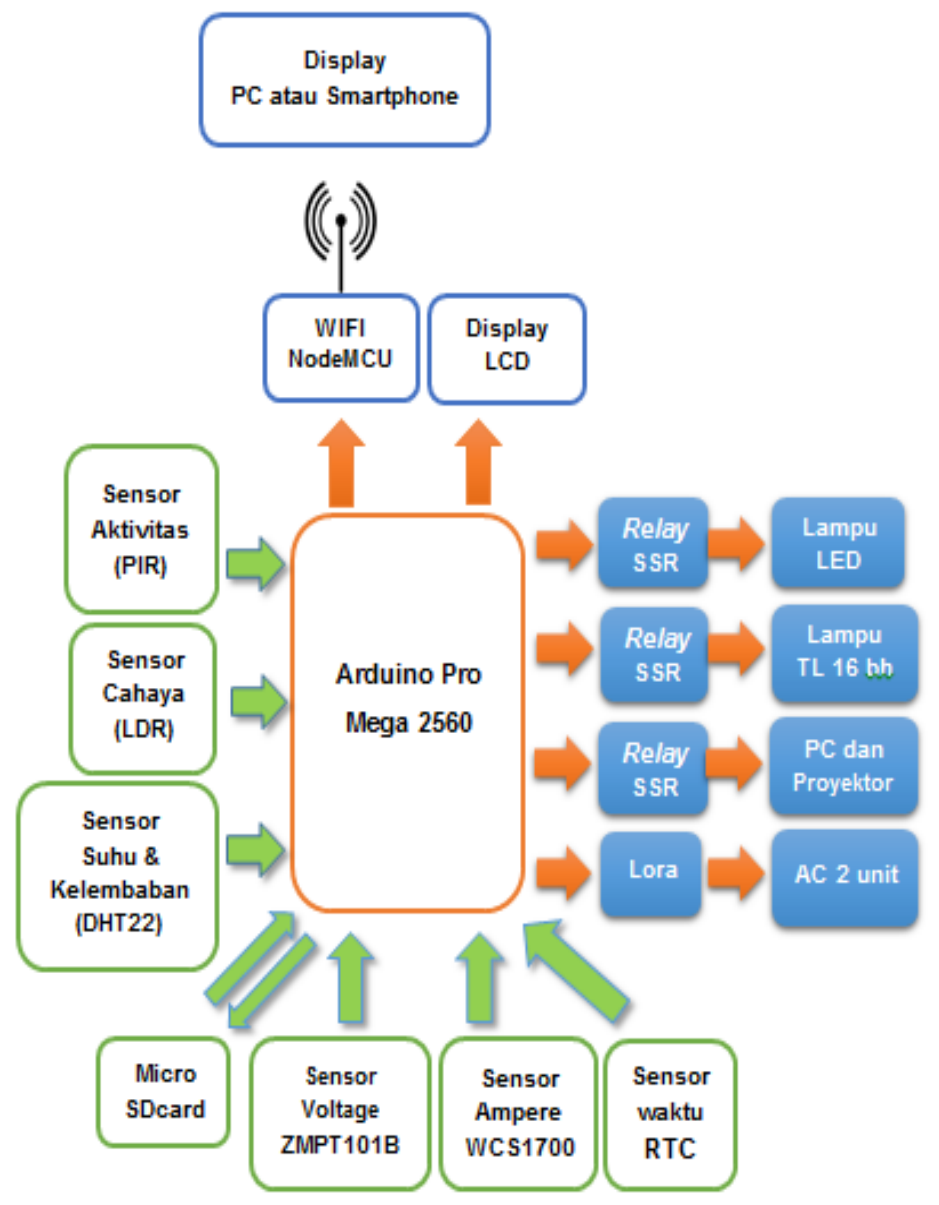

Figure 4. Block Design Prototype Diagram

\section{b. System Planning}

In system design, all components such as sensors, LCD displays, power supply, wifi, micro sdcard, and electrical loads are connected so that it can be controlled by Arduino Pro Mega 2560 so that it can get a tool that can automatically control and monitor and measure consumption electrical energy. To assemble this tool into one system, it is necessary to implement sub-systems design first. After all the components and modules are synchronized and connected, it can be continued with a series of components and tested functions one by one until all components are arranged into one system.

\subsubsection{Software Design}

The design of software is made in accordance with the purpose of research, namely making a tool that is capable of monitoring, measuring and controlling electricity consumption in a room. At the initial stage, the system will check the Arduino device and other components on the control sub-system and the KWh meter sub-system. Furthermore, the KWh meter sub system will read and measure the voltage, current, cos phi and time in the electrical circuit of the classroom. Meanwhile in the sub-system of control will identify the presence or absence of people in the classroom, if there is then the system will automatically turn on the $A C$ with the setpoint that has been determined. Furthermore, the system will measure the intensity of light in the room, if it is less than a setpoint then the lights in the class will automatically be turned on but if the light intensity exceeds the setpoint then the classroom lights will be turned off by the relay. The pattern of setting ON/OFF electrical equipment automatically is effective for reducing electricity consumption in the classroom. Because the electrical equipment will light only when needed. In addition, it is added to the pattern of setting the setpoint on the AC, so that the large electricity consumption of the AC compressor can also be suppressed.

To control the use of a PC, projector and notebook is only limited to the relay control to drain or cut off the electricity to the electrical equipment. Parameter readings on the activity sensor and light are carried out repeatedly in the time period specified in the system. The display on the LCD only displays information on time, date, day, temperature and humidity. Information and control 
of ON/OFF electrical equipment automatically and manually is on the smartphone interface via wifi. In addition, users can also directly monitor the amount of electricity usage in one month. All of this information and features are in this automation tool. Here are some images from the display on the LCD and smartphone when operating the automation tool.

\begin{tabular}{|c|c|c|c|}
\hline $\mid .+11 .+11$ & $3 \mathrm{~KB} / \mathrm{s}$ क्ष. & $1: 28$ & $\Delta * 98 \%$ \\
\hline & 192.168.0.110 & & (3) \\
\hline $\begin{array}{l}\text { Sist } \\
\text { Rua }\end{array}$ & $\begin{array}{l}\text { Monitoring } \\
\text { ng Kelas di ST }\end{array}$ & $\begin{array}{l}\text { Konsums } \\
\text { AL }\end{array}$ & Listrik \\
\hline No. & Parameter & Status & Keterangan \\
\hline 1 & Hari & Tuesday & \\
\hline 2 & Tanggal & 22.01 .2019 & \\
\hline 3 & Jam & 21:29:17 & \\
\hline 4 & Temperatur & $27.10^{\circ} \mathrm{C}$ & \\
\hline 5 & Humidity & $92.70 \%$ & \\
\hline 6 & Tegangan & 337.6 Volt & \\
\hline 7 & Arus & $9.48 \mathrm{Amp}$ & \\
\hline 8 & Cosphi & 0.00 & \\
\hline 9 & Daya & $4.00 \mathrm{Watt}$ & \\
\hline 10 & Lampu Penerangan & Mati & ON OFF \\
\hline 11 & Air Conditioner_1 & Mati & ON OFF \\
\hline 12 & Air Conditioner_2 & Mati & ON OFF \\
\hline 13 & Komputer \& LCD & Mati & ON OFF \\
\hline
\end{tabular}

Figure 5. Display Monitoring on Smartphone

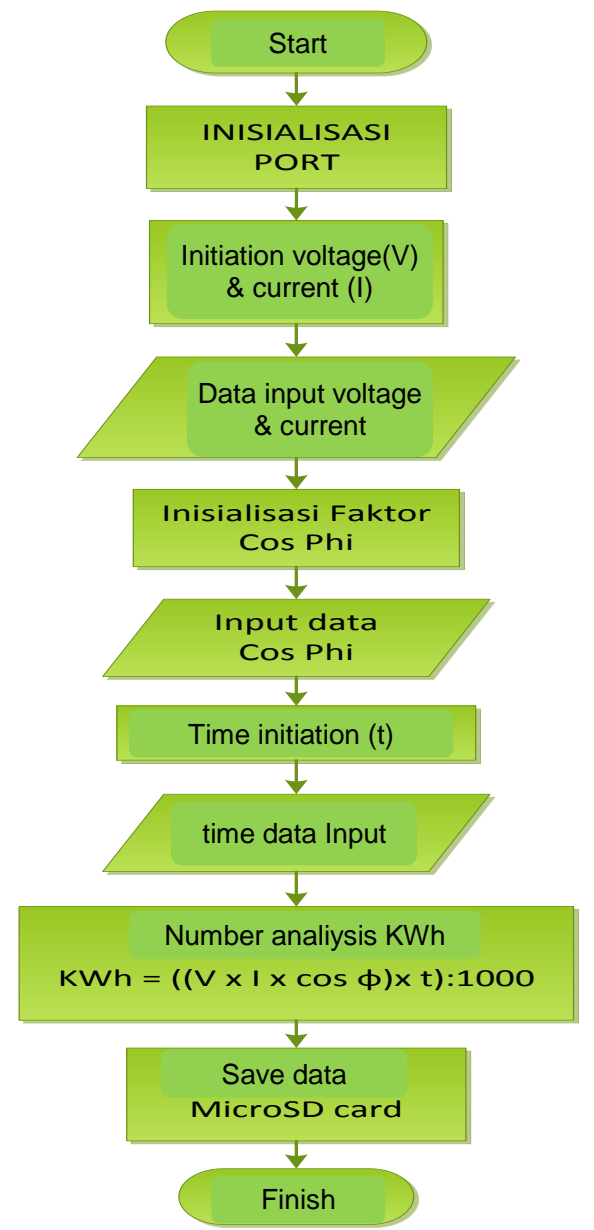

Figure 6. KWH Meter Flowchart.

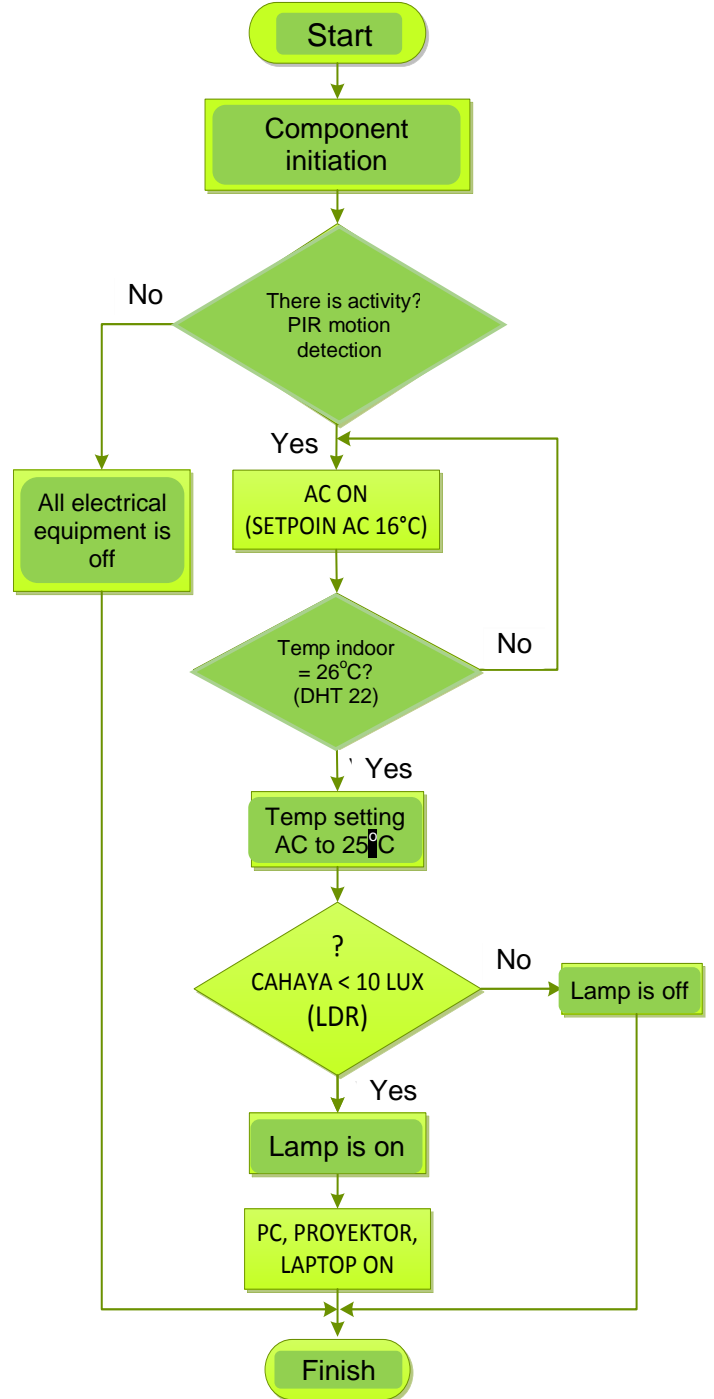

Figure 7. Control System Flowchart.

3.2.3 Result

a. Refrigration Time Data

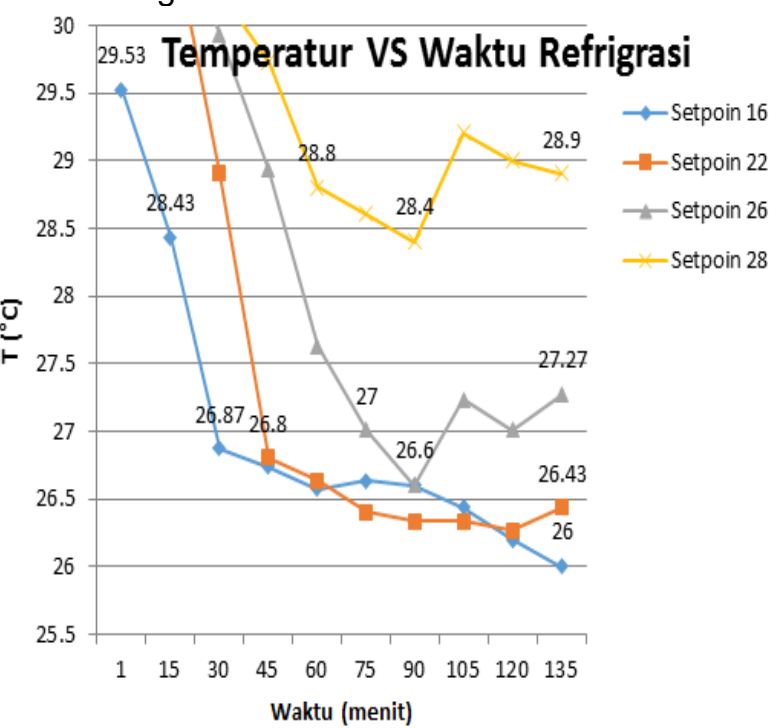

Figure 8. Graph of Temperature Relations with Refrigration Time. 
The setpoint with the fastest refraction time in figure 8 is used as the initial set point in the AC operation settings. So that when the $A C$ is turned on, the optimal comfortable classroom temperature $\left(25^{\circ} \mathrm{C}\right)$ can be quickly reached.

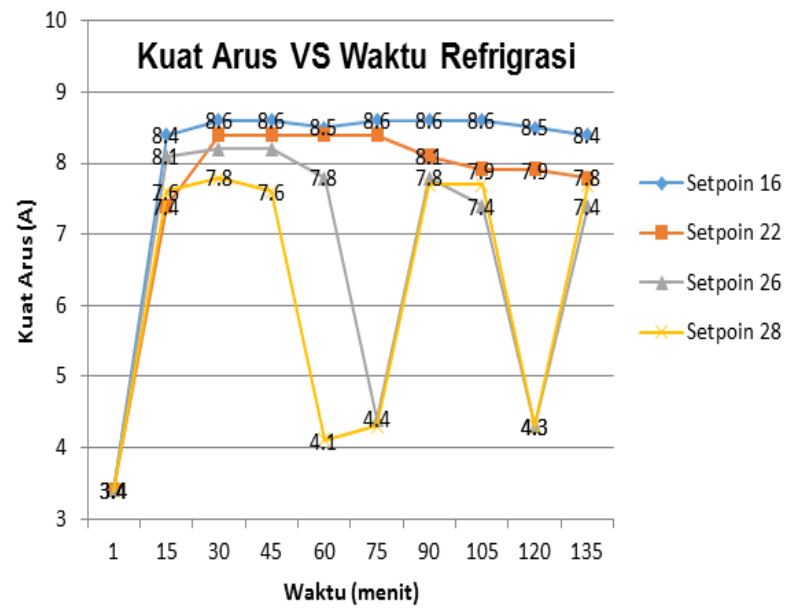

Figure 9. Graph of Current Charges Against Refrigration Time.

From the graph data in figure 9, it can be seen that the lowest electrical load in 135 minutes is set at points 28 and 26 . Therefore, setting the AC temperature setpoint will be set at a set of $25^{\circ} \mathrm{C}$. If the temperature sensor reads the classroom temperature close to $25^{\circ} \mathrm{C}$, the automation tool will change the AC setpoint to $25^{\circ} \mathrm{C}$. This command will be sent by an infrared led on Arduino Uno. This setpoint method is deemed appropriate because comfortable conditions can be quickly achieved and $\mathrm{AC}$ power consumption is also more economical.

b. Electricity Consumption Data

This data collection is carried out within 6 days, 3 days without tools and 3 days using tools. The data obtained are as follows:

Table 5. Electricity Consumption without Automation Equipment

\begin{tabular}{|c|c|c|c|}
\hline NO. & Time & $\begin{array}{c}\text { Consumption } \\
(\mathrm{KWh})\end{array}$ & Mark \\
\hline 1 & $08.01-12.00$ & 10,468 & Day-1 \\
\hline 2 & $12.01-16.00$ & 10,360 & \\
\hline 3 & $16.01-20.00$ & 6,368 & \\
\hline 4 & $20.01-00.00$ & 6,342 & \\
\hline 5 & $00.01-04.00$ & 6,358 & \\
\hline 6 & $04.01-08.00$ & 6,681 & \\
\hline 7 & $08.01-12.00$ & 10,498 & Day-2 \\
\hline 8 & $12.01-16.00$ & 10,416 & \\
\hline 9 & $16.01-20.00$ & 0,13 & \\
\hline 10 & $20.01-00.00$ & 0,092 & \\
\hline 11 & $00.01-04.00$ & 0.095 & \\
\hline 12 & $04.01-08.00$ & 1,676 & \\
\hline 13 & $08.01-12.00$ & 10,452 & Day-3 \\
\hline 14 & $12.01-16.00$ & 10,386 & \\
\hline 15 & $16.01-20.00$ & 0,14 & \\
\hline 16 & $20.01-00.00$ & 0,098 & \\
\hline 17 & $00.01-04.00$ & 0.094 & \\
\hline 18 & $04.01-08.00$ & 1,643 & \\
\hline & & & \\
\hline
\end{tabular}

Table 6. Electricity Consumption with Automation Equipment

\begin{tabular}{|c|c|c|c|}
\hline NO. & Time & $\begin{array}{c}\text { Consumption } \\
(\mathrm{KWh})\end{array}$ & Mark \\
\hline 1 & $08.01-12.00$ & 9,258 & Day-1 \\
\hline 2 & $12.01-16.00$ & 9,181 & \\
\hline 3 & $16.01-20.00$ & 0,115 & \\
\hline 4 & $20.01-00.00$ & 0,075 & \\
\hline 5 & $00.01-04.00$ & 0,095 & Day-2 \\
\hline 6 & $04.01-08.00$ & 1,734 & \\
\hline 7 & $08.01-12.00$ & 9,358 & \\
\hline 8 & $12.01-16.00$ & 9,151 & \\
\hline 9 & $16.01-20.00$ & 0,128 & Day-3 \\
\hline 10 & $20.01-00.00$ & 0,066 & \\
\hline 11 & $00.01-04.00$ & 0,092 & \\
\hline 12 & $04.01-08.00$ & 1,775 & \\
\hline 13 & $08.01-12.00$ & 9,288 & \\
\hline 14 & $12.01-16.00$ & 9,136 & \\
\hline 15 & $16.01-20.00$ & 0,126 & \\
\hline 16 & $20.01-00.00$ & 0,076 & \\
\hline 17 & $00.01-04.00$ & 0,094 & \\
\hline 18 & $04.01-08.00$ & 1,735 & \\
\hline
\end{tabular}

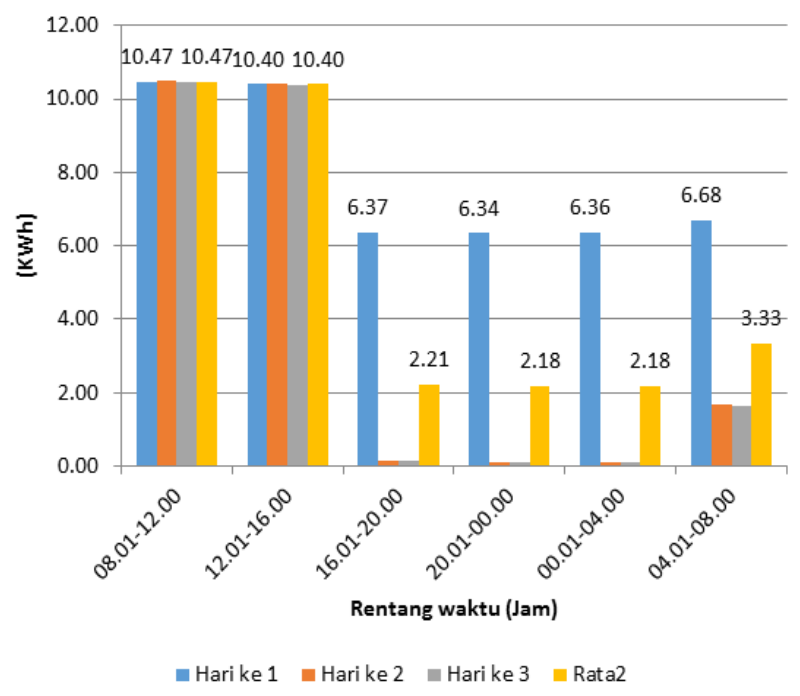

Figure 10. Electricity Consumption Chart without Automation Tool.

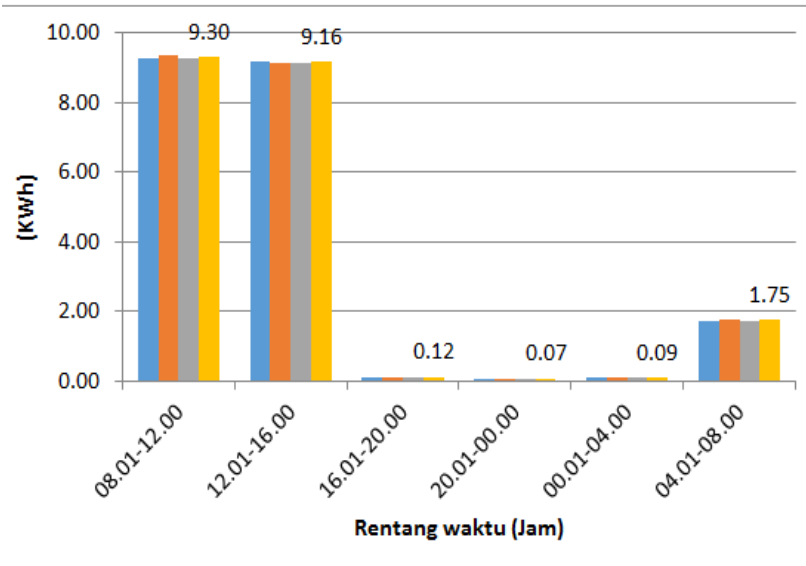

- Hari ke 1 Hari ke 2 Hari ke 3 Rata2

Figure 11. Electricity Consumption Chart with Automation Tool 


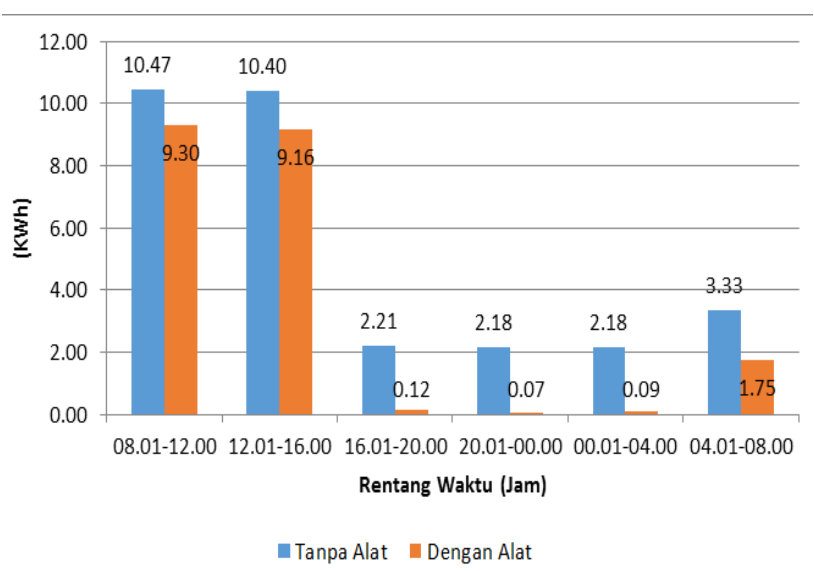

Figure 12. Graph of Average Comparison of Amount of Electricity Consumption.

\subsection{Discussion}

From the data of electricity consumption for 6 days we get 3 days of electricity consumption data without an automation tool and 3 days of electricity consumption data using an automation tool. From both of these data both as a whole and partially the time interval, there are differences in the amount of electricity consumption. Electricity usage in table 7 is relatively lower than electricity usage in table 8 .

In the variable amount of electricity usage in general there are differences in usage at each time interval in 1 day. Electricity usage in 1 day starts to increase at intervals of 04.00 to 08.00 . Electricity consumption at 08.00-12.00 and 12.00-16.00 is relatively high. Electricity consumption began to decline again at 16.00-20.00 and continued to decline until 04.00 the next day. Data on day 1 (without automation tools) at 4:00 p.m. 04.00, the electricity consumption of classrooms remains high compared to days 2 and 3 . This indicates that there is a negligence of users in controlling the use of electrical equipment when leaving the classroom so that there is a waste of electricity consumption when the class is not used.

The graph in figure 12 is a graph of the comparison of the average amount of electricity usage with an automation tool and without an automation tool. This graph compares the average value of total electricity usage in 3 days at each time interval. The result is that electricity consumption with automation equipment is lower than electricity consumption without automation tools. To measure the level of savings achieved, the automation tool needs to be calculated using the following amount of consumption:

Table.7. Comparison of Total Electricity Consumption During Experiments.

\begin{tabular}{|r|l|r|r|}
\hline \multirow{2}{*}{ No } & \multirow{2}{*}{ Trial } & \multicolumn{2}{|c|}{ Comsumtion (KWh) } \\
\cline { 3 - 4 } & & with auto tools. & without auto tools. \\
\hline 1 & Day-1 & 46,62 & 21,46 \\
\hline 2 & Days-2 & 22,9 & 20,57 \\
\hline 3 & Days-3 & 22,81 & 20,46 \\
\hline \multicolumn{2}{|r|}{ Rate } & 30,78 & 20,49 \\
\hline \multicolumn{2}{|r|}{} \\
\hline
\end{tabular}

Savings on day 1 :

$$
\text { Savings }=\frac{46,62-20,46}{46,62} \times 100 \%=56,11 \%
$$

Savings on day 2 and 3 :

$$
\text { Savings }=\frac{22,86-20,51}{22,86} \times 100 \%=10,26 \%
$$

Average savings :

$$
\text { Savings }=\frac{30,78-20,49}{30,78} \times 100 \%=33,43 \%
$$

From the results of the calculation above, saving electricity consumption on day 1 is $56.11 \%$, days 2 and 3 are $10.26 \%$ and the average savings for the 6-day trial is $33.43 \%$. This means that electricity consumption that can be saved by using an automation tool in 1 day of classroom use without the negligence of user control is $\pm 10.26 \%$ of class electricity consumption without using automation tools and if there is a factor of user negligence the automation tool can save electricity consumption more than $33.43 \%$ of electricity consumption without using automation tools.

Overall, the results of the analysis of the 6day trial are that this tool is effective for saving electricity consumption in the classroom. Evident from the results of experiments and analysis on STTAL classrooms with AC capacity that is less than the heat load, this tool is able to save electricity consumption on average by $33.43 \%$. This tool is able to control the use of electrical equipment by using an automated system of components and microcontrollers in it. In addition, information about the amount of electricity consumption and control features of ON/OFF electrical equipment in the class can also be accessed with a smartphone via a wifi network.

\section{CONCLUSION}

From the results of calculations, data collection and analysis on research objects in the span of 6 days found several conclusions, including:

a. The installed engine coolant capacity does not match the heat load in the classroom. The results of calculating the total heat load in the classroom are 32,048.3 BTU, equivalent to $\pm 4 \mathrm{PK}$.

b. The workings of this automation tool by controlling the use of electrical equipment automatically with parameters specified in the Arduino program so as to save electricity consumption.

c. This automation tool is effective for saving electricity consumption and controlling the use of electrical equipment in classrooms. Evident from the results of the analysis, the average savings for the 6 -day trial was $33.43 \%$. In addition, information about the amount of electricity consumption and control features of ON / OFF electrical equipment in the class can be accessed with a smartphone via a wifi network so that users will find it easier to monitor the use of electrical equipment in the classroom. 
In addition there are a number of suggestions for continuing this research, including:

a. For further research, the results of this study can be developed into an application that can monitor electricity consumption in all rooms in an office. So that all data can be integrated and monitored in one application.

b. For safety in applying this tool, it is necessary to implement a relay component replacement according to industry standards equipped with a circuit breaker safety.

\section{REFERENCES}

Abubakar. (2014). Mekatronika. Aceh: Malikussaleh University School of Engineering.

Development, U. I. (2014). Energy Saving Guide in Government Buildings. Jakarta: www.iced.or.id.

Ibrahim, M. M. (n.d.). Do it yourself, Smart Energy Monitor. Mansoura, Egypt: Infinity tech.J.P.Holman. (1986). Sixth Edition Heat Transfer. (E.Jasjfi, Trans.) Jakarta: Erlangga. Retrieved 1997

Kimmo Karvinen, Tero Karvinen. (2014). Getting Started with Sensors. Sebastopol: Maker
Media.

Octarina Nur Samijayani, Ibnu Fauzi. (2015). Smart Home Design Based on Wireless Sensor Networks. AL-Azhar Indonesia Journal of Science and Technology Volume 3 Number 2, 76-81.

Riley, M. (2012). Programming Your Home. Dallas: The Pragmatic Programmers.

Schwartz, M. (2014). Arduino Home Automation Projects. Birmingham-Mumbai: Packt Publishing Ltd.

Tanjung, A. (2017). Power Monitoring System Prototype On KWh Meter 1 Phase And Control System On / Off Via Sms Module. UMRAH Electrical Engineering, 1-7.

Wilyanto, Firdaus, Wahyudi Budi Pramono, Ida Nurcahyani. (2017). Lighting Arrangement System in Lecture Rooms to Support Energysaving Programs based on wireless sensor networks. 4th SNATIVE, 153-160.

Wiranto Arismunandar, Heizo Saito. (1991). Air Refresher. Jakarta: Pradya Paramita. 